\title{
Soft Skills and Technical Expertise of Effective Project Managers
}

\author{
Sharlett Gillard \\ University of Southern Indiana, Evansville, IN, USA \\ sgillard@usi.edu
}

\begin{abstract}
As the field of research surrounding project management continues to grow, it is becoming more evident that success in the role of project manager cannot be attained with a technical skill set only. Project managers functioning within a matrix organizational structure and championing large-scale initiatives are in a communication paradigm unparalleled by any other management position. Excellent interpersonal, or soft skills, are necessary requisites for success. Additionally, research is revealing that leading is preferable to managing a project team, and that the leadership style of the project manager directly impacts the outcome of the project. The article presents an overview of these tenets drawn from opinion positions, practical experiences, and empirical research studies. There is clear evidence that additional empirical research would be beneficial.
\end{abstract}

Keywords: soft skills, project management, leadership.

\section{Introduction}

Project management emerged as a methodology for managing initiatives that not only focused on creating a one-time product or prototype but also required the expertise of individuals from crossdepartmental boundaries. Most large-scale projects required input and personnel from functional, technical and support departments working under the auspices of a project manager. In response, many companies migrated from the traditional hierarchy organizational structure to a matrix organizational structure designed to spread scarce technical manpower resources throughout largescale, cross-departmental projects.

In large-scale organizations, project managers oversee two types of subordinate groups. One group includes project team members permanently assigned to the project office and solely under the project manager's authority. The second group consists of subject matter experts from the organization's functional, technical, and support departments who are temporarily attached to the project team but remain assigned to the ir parent department. Those employees are responsible to both their department supervisor and the project manager (Dunn, 2001; Harrison, 1981, p. 17).

Material published as part of this publication, either on-line or in print, is copy righted by the Informing Science Institute. Permission to make digital or paper copy of part or all of these works for personal or classroom use is granted without fee provided that the copies are not made or distributed for profit or commercial advantage AND that copies 1) bear this notice in full and 2) give the full citation on the first page. It is permissible to abstract these works so long as credit is given. To copy in all other cases or to republish or to post on a server or to redistribute to lists requires specific permission and payment of a fee. Contact Publisher@InformingScience.org to request redistribution permission.
This dual-leadership role required of the project manager underscores the importance of solid leadership skills for effective project management. Smaller organizations may not maintain a permanent Project Office, and the project manager resides within the functional organization. The physical arrangement, however, does not diminish the complex role of the typical project manager. 
The project manager is responsible for meeting project objectives, for schedules, budgets, and assessing alternatives, for assessing risks and deciding how to accept, avoid, remove, or mitigate them, and for leading the initiative to successful completion (Baca, 2007; DiVincenzo, 2006; Dunn, 2001; Zielinski, 2005). Managers of the functional, technical, and support departments provide personnel and technical assistance to the project manager, yet retain responsibility for their tools, training, performance evaluation, and reassignment (Jacques, Garger, \& Thomas, 2008; Wellman, 2007).

A further complication of the project manager's role stems from the multi-dimensional environment in which s/he functions. At the core of day-to-day operations is the project office and the project team. A second dimension is the intra-organization-the parent organization, user community, and contractor(s). And a third dimension is the inter-organization-external organizations having a vested interest, or oversight authority in the project office. This complex environment presents a communication paradigm unparalle led by any other management position: The team is often large in number and consists of a multi-faceted mix of multi-disciplinary, interorganizational, geographically dis bursed members, internally employed personnel, and outsourced or contract staff; the project manager must cope with tenuous lines of authority and power; and the project manager must interact with multiple, varied groups and stakeholders inside and outside of the employing organization, often with conflicting interests relevant to the project at hand (Gillard, 2005).

As stated by Zielinski (2005, p. 18), 'these 'accidental' [project] managers must simultaneously satisfy the needs of often finicky clients, adhere to tight deadlines, and marshal limited or sometimes nonexistent resources to get the job done--all while shepherding, motivating and cajoling a diverse universe of personalities up and down the organizational food chain. They are held accountable for project results, but often have little power over personnel or resource matters--and they must find a way to get things done without ruffling too many feathers, because the next project on the docket might involve many of the same people."

Responsibility without authority is yet another challenge that the project manager faces. When team members have a dual reporting structure, the project manager may find it difficult to exert influence over the team members. Direct authority over personnel tends to rest with the functional manager, while the project manager has little direct authority over the project team members or their managers (Black, 2006; Dunn, 2001; Jacques, Garger, \& Thomas, 2008; Sy and D'Annunzio, 2005). It takes skill and finesse to lead a project to a successful conclusion given the intricacies of the job of a project manager.

Thus the repeating dilemma of the skill set best suited to a successful project manager.

\section{Technical Expertise}

All managers plan and manage projects. Some projects are quite narrow in scope and are carried out within a single department. For example a marketing plan for a new product may be designed by one individual or by individuals within one department. Broader projects, for example a merger, may include numerous people within and outside an organization, likely in geographically dispersed locations.

When the size of the initiative requires formation of a project team, members traditionally were chosen for their technical expertise. A prime example is provided by the information technology (IT) arena. The organization of project teams in the IT arena grew from a need for technical expertise in systems analys is and design as well as a need for subject matter expertise from functional area departments. Since the thrust of the initiative was the design, development, and installation of an information system, project management was traditionally awarded to a technical rather than a functional area expert, without regard to leadership skills. 
Authors such as Mantel and Meredith (1986) posited that some of the overriding factors leading to successful project management included technical credibility and the ability to use a systems approach for completing tasks that met performance standards on time and within planned costs. They claimed that industrial engineers were best suited for project management ventures based on their training, experience, and educational background. Ergo, the focus of project-management training has been on the technical skills deemed essential to the position, from mastering planning or budgeting processes to cost containment and evaluating risk (Zielinski, 2005).

Bacca (2007), however, posits that because engineers who are pressed into the role of project manager often focus on technical issues while giving management aspects less credence, they fall short of relating their game plans to the overarching strategy of the organization.

While there is general agreement that a project's success or failure hinges on the abilities of the project manager, there remains a difference of opinion as to what factors are the most important indicators of an effective project manager. Some, though seemingly a declining number, still cling to the opinion that the technical expertise of the project manager is of paramount importance for success; others suggest that interpersonal or "soft" skills are the primary determinant of success; and still others hold that both technical background and leadership skills are necessary for project management success.

\section{Interpersonal "Soft" Skills}

Sampson (2007, p. 41) writes, "The skills required for project management are now often divided 50/50 into traditional 'hard' skills, such as risk management and scheduling, and 'soft', peopleoriented skills, such as interpersonal communication." Drossel (1980) places leadership skills on the same level as any other technical activity with which the project manager is faced and writes that project success is based on planning, establishing an effective team, feedback through team meetings, and commitment to the task at hand. Zachary (1984) also suggests a balance between the technical and leadership aspects of project management and states that the project manager's goals are to build team morale and foster good working relations so everyone is eager to work toward a common goal--project completion. VanIngen (2007) notes that effective project management is a balance of organizational skills and people skills; and Corcoran (1997, p. 125) contends that "Ideal IT managers offer a blend of business and technical know-how. An MBA is helpful, but effective IT managers also need a technical background. They should understand the complex issues and trade-offs of new technologies."

Zielinski (2005, p. 22), however, points out that "If you had asked project-management gurus five years ago to name the most important competencies project managers should have, most would have said technical skills. Today they'd be more inclined to place communications or negotiations acumen at the top of their lists ... There's no denying the importance of technical expertise to successfully orchestrating a project. Managing an initiative's scope, cost, risk, resources and schedule are all essential skills. Indeed, the quality of up-front planning--and a project leader's skill at replanning as project conditions change--can determine a project's fate all on its own. But in rethinking skill hierarchies, many companies have come to view these more as baseline competencies. Now they regard soft skills ... such as communication, negotiation, conflict management and persuasion, as higher-order skills."

Almost two decades earlier Posner (1987) made a similar observation and noted that the fundamental problems confronting a project manager are related to the management of people, not to the technical challenges. He further asserted that a lack of organization and management skills are the primary reasons project managers fail. Brousseau (1987) agreed with him, maintaining that flexible leadership style and well executed management are essential to successfully managed projects. He carried the argument a step further by stating that the communications and 
leadership skills of a project manager are more important than are the technical skills. He further suggested that these interpersonal skills should be considered by top management when selecting a project manager. Almost 20 years later the same cry is being heard.

There is seemingly a general consensus that project managers have to become great communicators. The list of additional skills and abilities contributing to project success seems endless: Political savvy, an understanding of employee motivation, organizational dynamics, and team behavior (Brandel, 2006); an ability to delegate, coordinate ideas of diverse individuals, be flexible, and deal well w ith risk and stress (DiVincenzo, 2006); be results oriented, have strong interpersonal skills, understand the organization, be committed to corporate values, exercise a strong leadership style characterized by authority, responsibility, adaptability, and interface management, and be committed to control and planning (Kerzner, 1987); be able to effectively direct teams (Sacco, 2006); planning, negotiating and consensus-building (Black, 2006); and networking (Jiang, Kle in, \& Chen, 2001) to name but a few. One recurring theme does seem to be clear: the effective project manager must exercise strong leadership skills.

Leadership is different from management, requires different know ledge, a different skill set, and accomplishes a different purpose. Management deals with the present; leadership deals with the future. Management deals with resources; leadership deals with people and personalities. Management deals with facts; leadership deals with ideas (Van Ingen, 2007). The question, of course, is what types of leadership styles are best suited for the project management/matrix organization environment.

\section{Leadership Style}

Hersey and Blanchard $(1981,1988)$ recognized the contributions of leadership style to management effectiveness and noted that subordinates and the work place situation are key factors to consider when selecting an appropriate leadership style. From this precept, Hersey and Blanchard made an important addition to situational leadership theory by including the "maturity" of the follower as a component of the work place situation. Their definition of maturity has two subdimensions: job maturity, or task behavior; and psychological maturity, or relationship behavior. This, according to Hersey and Blanchard, means that effective leaders assess their subordinate's aptitude to accomplish a given task, gauge the subordinate's attitude for performing that task, and then select the most appropriate leadership style for that subordinate in a given work place situation.

A number of well-noted theorists have referred to the practicality of situational leadership theory for studying leadership in a project management, or matrix organization environment. For example, Yukl (1981) praised situational leadership for emphasizing the importance of leaders being flexible and adaptable; demonstrating that individual subordinates should be treated differently from one another; acknowledging that changing situations call for modif ied leadership styles; and recognizing that situations can be altered by developing the skills and raising the confidence of subordinates.

Cleland and Kerzner (1986, pg 101) asserted that the emphasis on "... flexible and dynamic [leadership] rather than static and rigid ... [leadership makes situational leadership theory] the best model for analyzing leadership in a project management environment...."

To be considered effective, project managers should exercise the appropriate style for each type of subordinate, assigned and attached. Hersey and Blanchard reported that for countries with high education levels and significant industrialization, most organization leaders use a combination of "Selling" and "Partic ipating" leadership styles. They note that this is the appropriate style for most employees in most organizations. However, Hersey and Blanchard also note that the two other styles, "Telling" and "Delegating" have legitimate uses in organizations (1988). These 
styles are valuable in circumstances much like those described for the temporarily attached subordinates in the project management environment. Telling would be appropriate for the attached support personnel who are tasked with very specific administrative or operational duties and simply need to be directed to perform them. Similarly, functional experts placed on the matrix team would work best being delegated the responsibility to use their expertise and get the job done.

Price (1993) conducted an empirical investigation of sixty-five project offices spread throughout the United States. His research objective was to quantitatively measure project manager effectiveness, with the goal of distinguishing between the effective project managers and their lesser effective counterparts. To measure project manager effectiveness, Price developed five leadership-based criteria and thirteen management-based criteria. He then grouped the participating project managers into three categories: most effective, typical, and least effective. The results indicated that an effective project manager uses Coaching or Supporting leadership styles.

Scores for the Coaching Leadership style showed that project managers who rely primarily on Coaching leadership use their conceptual skills to make a point are proactive, and oriented towards efficiency. Additionally, they project self-confidence, communicate effectively (use of oral presentations), promote group cohesion (manage the group process), gain cooperation from others (use of socialized power), provide feedback (develop others), and use their unilateral power appropriately.

Supporting leadership is reflective of project managers who use their conceptual skills, are orientated toward efficiency, proactive, self-confident, good communicators, team builders (managing group process), make use of socialized power, develop others, and have stamina and adaptability. However, they are perceived by subordinates as not expressing themselves with emotion (spontaneous behavior) nor using their unilateral power appropriately.

Another research study (Hyvari, 2006) measured the characteristics of an effective project manager by means of leadership behavior in 14 managerial practices. The results of that study suggest that planning/organizing, networking and informing are the most significant managerial practices in the leadership behavior of project managers.

\section{Academic Background}

Underlying most project-management training efforts today are standards and practices created by the Project Management Institute (PMI). The group's Project Management Body of Knowledge (PMBOK), a distillation of the knowledge, skills, tools and techniques generally accepted as best practice in the discipline, serves as a training blueprint for many business organizations and educational institutions. The PMBOK details five key processes for the effective management of most projects (initiating, planning, executing, monitoring and controlling, and closing), as well as nine supporting know ledge areas (project integration, scope, time, cost, quality, human resource, communications, risk and procurement management).

The PMBOK Guide, now in its fourth edition, is a recommended text in some universities offering project management education, which prompted a research study into how well project management literature and university education equips potential project managers in the area of human skills. The study notes that the PMBOK Guide predominantly emphasizes the required 'hard (technical) skills' at the expense of the 'soft (human) skills'. The study further highlights the need for a balance between hard and soft skills within project management education in universities and suggests that educators within this discipline should recognize the importance of incorporating greater human skills aspects into the ir educational programs. (Pant \& Baroudi, 2008)

DiVincenzo (2006, p. 23) points out that an individual aspiring to be a project manager should take classes that emphasize communication, should have a solid background in mathematics, and 
a familiarity with personal computers. He further states that the potential project manager needs to have "at least a bachelor's degree, although it need not be in a business- or management-related concentration. In fact, a degree in a specific subject area is helpful for providing expertise and guidance on projects that require background knowledge."

Using the 18 separate leadership and management criteria developed for his study, Price (1993) found that the college degree most frequently held by project managers rated "Most Effective" was either in business or management. This contrasts with the types of college degrees reported by the project managers rated as "Typical" and "Least Effective" in the Price study.

And in a research initiative to explore the leadership style of graduate project management students vs. other MBA students, the researchers found that project management students rate themselves significantly higher on the concern for people leadership style and were found to have a balance between the concern for task and concern for people leadership style vs. MBA students. The researchers concluded that "individuals exhibiting a concern for people leadership style and those with a balance between concern for task and concern for people leadership styles are good candidates for project management positions as well as training/education in project management." (Jacques, Garger, \& Thomas, 2008, p. 4).

\section{Conclusion}

As the field of research surrounding project management continues to grow, it is becoming more evident that success in the role of project manager cannot be attained with a technical skill set only. Technical skills are being recognized as one of the minimal requirements for a project manager. The need for excellent interpersonal, or soft skills, are necessary requisites for success, and although some would disagree, others advocate that these are skills that can be taught (and learned) rather than skills that are innate or genetic. Further, research is revealing that leading is preferable to managing a project team, and that the leadership style of the project manager directly impacts the outcome of the project.

\section{References}

Baca, C.M. (2007). Project manager! Who? Me? Machine Design, 79(20), 64-66.

Black, R. (2006). The psychology behind true project success. Computing Canada, 32(6), 19.

Brandel, M. (2006). The NEW project manager. Computerworld,40(15), 43-45.

Brousseau, J. (1987). Project management: People are the key resources. Computing Canada, 2, 17-19.

Cleland, D. I., \& Kerzner, H. (1986). Engineering team management. New York: Van Nostrand Reinhold Company.

Corcoran, C. T. (1997). How to find an IT management job. InfoWorld, 19(48), 125.

DiVincenzo, T. (2006). Project managers stay in charge and out front. Occupational Outlook Quarterly, 50(2) $19-25$.

Drossel, M. (1980). Organizing a project team. IEEE Transactions on Professional Communication, 3, 148150 .

Dunn, S. C. (2001). Motivation by project and functional managers in matrix organizations. Engineering Management Journal, 13(2), 3-10.

Gillard, S. (2005). The competencies of effective project managers: A conceptual analysis. International Journal of Management, 22(1), 48-53.

Harrison, F. L. (1981). Advanced project management. New York: John Wiley \& Sons. 
Hersey, P., \& Blanchard, K. H. (1981). So you want to know your leadership style? Training and Development Journal, 34-54.

Hersey, P., \& Blanchard, K. H. (1988). Management of organizational behavior: Utilizing human resource. (5th ed.), (p. 289). Englewood Cliffs, NJ: Prentice-Hall.

Hyvari, I. (2006). Project management effectiveness in project-oriented business organizations. International Journal of Project Management, 24(3), 216.

Jacques, P. H., Garger, J., \& Thomas, M. (2008). Assessing leader behaviors in project managers. Management Research News, 31(1), 4-11.

Jiang, J., Klein, G., \& Chen, H. (2001). The relative influence of IS project implementation policies and project leadership on eventual outcomes. Project Management Journal, 32(3), 49-55.

Kerzner, H. (1987). In search of excellence in project management. Joumal of Systems Management, 2, 30-39.

Mantel, S. J., Jr., \& Meredith, J. R. (1986). IEs are best suited to challenging role of project manager. Industrial Engineering, 4, 54-60.

Pant, I., \& Baroudi, B. (2008). Project manage ment education: The human skills imperative. International Journal of Project Management, 26(2), 124.

Posner, B. Z. (1987). What it takes to be a good project manager. Project Management Joumal, 1, 51-54.

Price, J. E. (1993). An investigation of the relationship between perceived leadership and managerial effectiveness in matrix organizations. Dissertation, George Mas on University, Fairfax, VA.

Sacco, R. (2006). Yogi Berra, PMP. Computerworld, 40(43), 44.

Sampson, B. (2007). Get with the project. Professional Engineering, 20(12), 41-42.

Sy, T., \& D'Annunzio, L. S. (2005). Challenges and strategies of matrix organizations: Top-level and midlevel managers' pers pectives. Human Resource Planning, 28(1), 39-49.

Van Ingen, S. (2007). Leadership of project teams. Chemical Engineering, 114(1), 55-58.

Wellman, J. (2007). Leadership behaviors in marix environ ments. Project Management Journal, 38(2), 6275.

Yukl, G. A. (1981). Leadership in Organizations (1st ed) (p. 144). Englewood Cliffs, N.J.: Prentice-Hall.

Zachary, W. B. \& Krone, R. M. (1984). Managing creative individuals in high-technology research projects. IEEE Transactions on Engineering Management, 1, 37-40.

Zielinski, D. (2005). Soft skills, hard truths. Training, 42(7), 18-22.

\section{Biography}

A professor of computer information systems at the University of Southern Indiana, Dr. Gillard's research interests include project management and curricular issues in CIS. Her non-teaching experience has included positions such as administrative assistant for a TV news broadcast program in Los Angeles, CIO for a senior adult care facility, PM for a consortium of developers, builders, and commercial real estate agents, administrator of a satellite college campus, and academic dean of a business college. 